УДК 621.382.029.6.001.63(045)

\title{
ШИРОКОПОЛОСНЫЙ УГЛОВОЙ ПЕРЕХОД ДЛЯ V-ДИАПАЗОНА
}

\author{
ЩЕРБИНА О. А. ${ }^{1}$, ЯЩИШИН Е. М. ${ }^{2}$ \\ ${ }^{1}$ Нацииональный авиационный университет, Украина, \\ Киев, 03058, пр-т Космонавта Комарова, 1 \\ ${ }^{2}$ Варшавский политехнический университет, \\ Польша, Варшава, 00661, пл. Политехники 1
}

\begin{abstract}
Аннотация. Предложена модель широкополосного перехода от прямоугольного волновода с воздушным заполнением к волноводу, интегрированному в подложку, для V-диапазона волн. Приведены теоретические принципы, на основе которых построена модель перехода
\end{abstract}

Ключевые слова: интегрированный в подложку волновод; переход; миллиметровый диапазон; RWG; SIW

\section{ВСТУПЛЕНИЕ}

В настоящее время наблюдается тенденция освоения миллиметрового спектра в диапазоне 30-300 ГГц коммерческими системами связи, где скорость передачи данных может значительно превышать 1 Гбит/с.

Одно из преимуществ использования этого диапазона заключается в малом размере антенны (половина длины волны на 60 ГГц составляет 2,5 мм). Это позволяет формировать элементы антенн на основе стандартной структуры для создания фазированных решеток с очень высоким коэффициентом усиления. Такие антенны возможно устанавливать на печатных платах, небольших подложках, кремниевых кристаллах.

В современном оборудовании уже используется миллиметровый диапазон волн. Например для ретрансляции в сотовых и других сетях используются частоты 60 и 80 ГГц. Автомобильные радары работают в диапазоне 77 ГГц аналогично другим военно-космическим системам. Каналы связи системы посадки беспилотных летательных аппаратов работают на частоте 35 ГГц. Однако реальные возможности этого диапазона могут быть реализованы в коммерческих и потребительских устройствах и системах.

В данной статье рассмотрено использование ISM (Industrial, Scientificand Medical Radio Band) диапазона (57-64 ГГц), выделенного Регламентом Радиосвязи для работы в промышленной, научной и медицинской областях [1].

\section{ПОСТАНОВКА ЗАДАЧИ}

В миллиметровом диапазоне существует значительное количество измерительных компонент, реализованных на стандартных прямоугольных волноводах с воздушным заполнением RWG (rectangular waveguide), которые обладают рядом преимуществ: большая мощность передачи, небольшие потери и полностью экранированная структура. Совместимость таких систем с компонентами, построенными на 